\title{
Local and regional environmental factors drive the spatial distribution of phototrophic biofilm assemblages in Mediterranean streams
}

\author{
Nina H. Witteveen (i) $\cdot$ Anna Freixa $\cdot$ Sergi Sabater
}

Received: 22 November 2019/Revised: 30 March 2020/Accepted: 7 April 2020/Published online: 24 April 2020

(C) The Author(s) 2020

\begin{abstract}
Temporary streams are submitted to high seasonal hydrological variations which induce habitat fragmentation. Global change promotes longer nonflow periods, affecting hydrological continuity and the distribution of biological assemblages in river networks. We aimed to investigate the effects of hydrological discontinuity on phototrophic biofilm assemblages in a Mediterranean stream, at both network and habitat scales. At the network scale during basal flow conditions, mostly nitrate and DOC concentrations were associated to the taxonomical and
\end{abstract}

Handling editor: Judit Padisák

Electronic supplementary material The online version of this article (https://doi.org/10.1007/s10750-020-04258-2) contains supplementary material, which is available to authorized users.

\section{N. H. Witteveen $(\bowtie)$}

University of Amsterdam, 904 Science Park, 1098 GE Amsterdam, The Netherlands e-mail: n.h.witteveen@uva.nl

A. Freixa $\cdot$ S. Sabater

Catalan Institute for Water Research (ICRA), Emili Grahit 101, 17003 Girona, Spain

A. Freixa

University of Girona, 17003 Girona, Spain

S. Sabater

Institute of Aquatic Ecology, Faculty of Sciences,

University of Girona, 17003 Girona, Spain trait distribution of algae and cyanobacterial assemblages. Cyanobacteria dominated at the upstream and downstream sites of the network, while green algae and diatoms were abundant in its middle part. At the habitat scale, hydrological discontinuity promoted large changes in biofilm composition between riffles and pools, where pools were inhabited preferentially by green algae and riffle habitats by cyanobacteria. Our findings emphasize the myriad of factors affecting the spatial distribution of phototrophic biofilms, which become more heterogeneous according to water flow interruption. Under the predicted climate change scenarios, spatial heterogeneity in temporary streams may increase, which will lead to change phototrophic biofilm assemblages.

Keywords Algae $\cdot$ Cyanobacteria $\cdot$ Flow disconnection - Traits - Taxonomy

\section{Introduction}

Temporary streams characteristically cease to flow at some point in space and time (Boithias et al., 2014), experiencing cycles of expansion, contraction and fragmentation (Acuña et al., 2005). Temporary streams make up at least $30 \%$ length of the global river network (Acuña et al., 2014), this proportion being larger in dry or semi-dry areas. In the 
Mediterranean basin, temporary streams receive both natural and human-derived hydrological disturbances, which cause highly seasonal and interannual hydrological variations (Sabater \& Tockner, 2009). The Mediterranean region is also a "hot-spot" of biodiversity (Myers et al., 2000), as well as one of the areas vulnerable to climate change (Giorgi \& Lionello, 2008). These alterations will cause a likely reduction of summer precipitation, up to $4^{\circ} \mathrm{C}$ warming, and higher frequency of extreme precipitation events (i.e. droughts and heavy rainfalls) (Sánchez et al., 2004), which will translate to a higher flow variability and longer periods of flow interruption in temporary streams (Acuña et al., 2017).

Alterations in the river hydrological regime may affect stream biota, privileging the most adaptive taxa and causing local and regional changes in diversity (Bonada \& Resh, 2013). Being placed at the basis of the stream trophic network, biofilms are complex biological communities of bacteria, fungi, cyanobacteria, algae and protozoa (Lock 1984). In small streams, phototrophic epilithic biofilms (developing mostly on the upper parts of cobbles and rocks) are usually dominated by eukaryotic algae and cyanobacteria (Lock, 1993; Romani \& Sabater, 2000). These are involved in the biogeochemical cycling of nutrients and organic matter (Von Schiller et al., 2007; Lange et al., 2011; Battin et al., 2016), and provide a good quality food source for consumers (Bott \& Kaplan, 1990; Stevenson, 1996; Graba et al., 2013) within river networks.

Variations in river hydrology and the magnitude and frequency of flow pulse events, together with the stream size, and its location within the network might influence the spatial distribution of phototrophic biofilms species in temporary streams. The composition and abundance of phototrophic epilithic biofilms is responsive to variations in hydrology, substrata size and texture, light irradiance, temperature, and nutrient conditions (Stevenson, 1996; Battin et al., 2016). In the hydrological transition between basal flow and non-flow conditions (which may occur at the intersection between early spring and summer in Mediterranean temporary streams), environmental differences between the sites occur swiftly and are spatially evidenced, and local factors impose large differences at the habitat scale (Tornés and Sabater 2010, Stanley et al., 2004; Ledger et al., 2008). The stream network becomes fragmented, remaining into a patched landscape of pools and riffles, leading to a mosaic of contrasting habitats, to be colonized by phototrophic biofilms. Their composition and abundance, as a result, might differ both longitudinally (along the channel) and laterally (across the channel), and potentially produce characteristic patterns of alpha and beta diversity between the sites (Socolar et al., 2016; Pound et al., 2019). Beta diversity may increase when habitat patches become disconnected in parallel to the hydrological interruption (Larned et al., 2010). Overall, the composition of biofilm communities might be seen as the output of local (on-site) and network scales.

In this study, we analysed the taxonomical and trait distribution of phototrophic biofilm assemblages at the network and habitat scales during this transitional period in the hydrology of a Mediterranean river. Species might possess traits facilitating their colonization success as well as the individuals' survival (McAbendroth et al., 2005; Tornés \& Ruhí, 2013), and therefore are informative of their adaptations to a changing environment. Combining taxonomical and trait-based approaches may be helpful to understand the patterns of distribution of species assemblages (Kelly, 2012; Tapolczai et al., 2016; Wu et al., 2017). Through them, we aimed to test that the environmental drivers characterizing the interphase between the basal water flow period and the disconnection period would consistently affect the composition and trait distribution of phototrophic biofilm assemblages at different spatial scales. We assumed that (i) environmental characteristics such as light availability, flow velocity, and nutrient content would account for the distribution of phototrophic biofilm species at the network scale. Headwater sites have lower nutrient content and lower light availability than downstream sites, and these usually favour different patterns of taxonomical composition and species traits (Sabater et al., 2006). We expected that differences along the network would be more important than potential variations within each of the sites. We also aimed to test that (ii) at the habitat scale, habitat type and the degree of hydrological separation would be the most important drivers of phototrophic biofilm communities. We expected riffle habitats to sustain more homogeneous physical and chemical conditions between them than isolated pool habitats, and that these differences would revert on distinct biofilm assemblages between them. Finally, (iii) we assumed that differences along the 
network and between habitats would consistently appear at both taxonomical and trait features.

\section{Methods}

Study area and sampling strategy

The study was performed in the Algars-Estrets river network (NE Iberian Peninsula). This is a small basin $\left(405 \mathrm{~km}^{2}\right)$ receiving a moderate human pressure, mostly in its lower part in the form of agricultural activities (CORINE land cover data 2006). In the upper part of the basin coniferous forest and transitional woodland-shrub dominate, and middle reaches are characterized by a mixture of coniferous forest with agricultural land. The basin has a Mediterranean climate, with a dry summer period and a wet period in autumn and spring, and the river network receives a highly predictable and seasonal hydrological variation (Gasith \& Resh, 1999). During the drier period (May to September), flow interruption affects hydrological connectivity and increases habitat heterogeneity (Gasith \& Resh, 1999; Matthaei et al., 2003). A two-scale sampling design was performed, aiming to unveil the detailed (habitat, local scale) and general distribution of algal river communities (sites scattered from upstream to downstream along a river network).

\section{Network scale}

We performed a field survey for the assessment of the spatial distribution of phototrophic biofilms species. We selected 14 sites distributed throughout the Algars-Estrets river network (Fig. 1), and sampled during baseflow (February 2019), when longitudinal hydrological connectivity was complete but lateral connectivity was partial at some sites. We will refer to samples from this fieldwork survey as the network scale samples. The sampled sites alternated riffles and pools, with streambed substrata of cobbles of decreasing size downstream. In every site, three equidistant transects including riffle and pool habitats were defined and sampled. Discharge from the closest gauge in the Algars was $0.17 \mathrm{~m}^{3} \mathrm{~s}^{-1}$ (between sites A3 and A4; data from www.chebro.es).

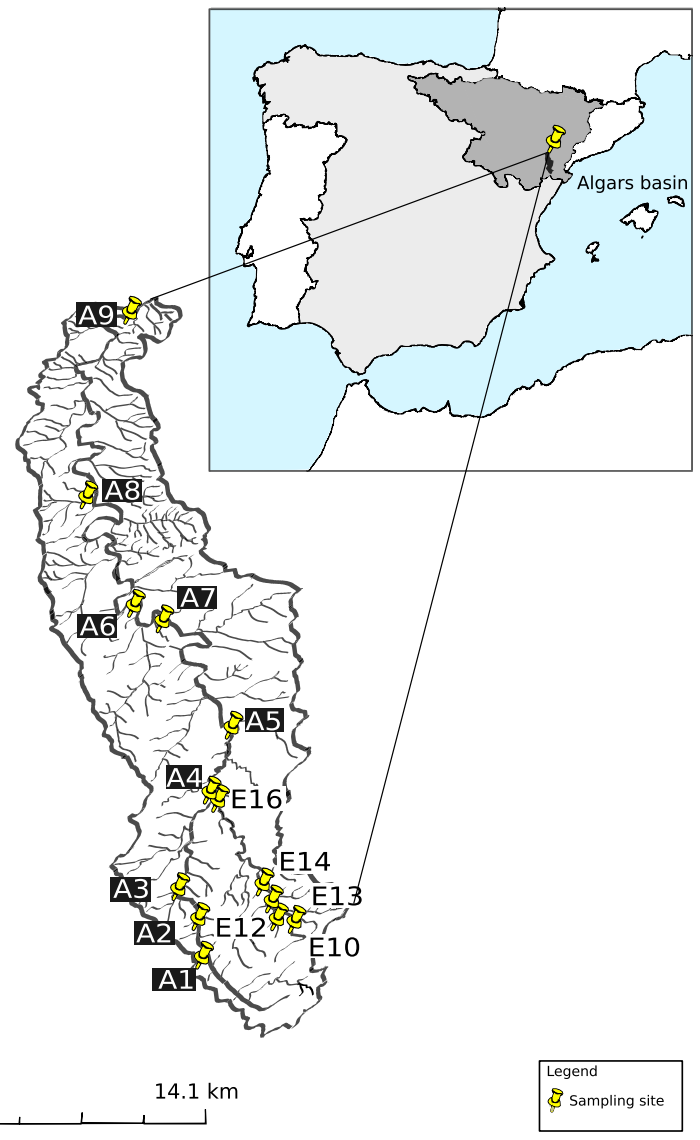

Fig. 1 Location of the Algars-Estrets river network in the Iberian Peninsula (map in the upper right corner). Yellow thumbtacks indicate the sampling sites. A total of 9 sampling sites of the Algars ('A') river and 5 sampling sites of the Estrets ('E') river are shown

\section{Habitat scale}

We also performed a separate second sampling campaign during April 2019. Two of the sites already sampled (sites A3 and A9, Fig. 1) were selected for a detailed analysis of the spatial distribution of the phototrophic biofilm assemblages. We will refer to samples from this field survey as the habitat scale samples. This period was still in baseflow $\left(0.15 \mathrm{~m}^{3} \mathrm{~s}^{-1}\right.$ between sites A3 and A4), but hydrological fragmentation was apparent mostly in site A9. We selected three different riffle habitats and two pool habitats in each of the two studied sites, onto which 3 replicates were sampled for each riffle or pool habitat and, each replicate consisting of 3 independent cobbles. 


\section{Physical and chemical variables}

Electrical conductivity $\left(\mu \mathrm{S} \mathrm{cm}{ }^{-1}\right), \mathrm{pH}$, water temperature $\left({ }^{\circ} \mathrm{C}\right)$ and dissolved oxygen concentrations $(\mathrm{mg}$ $1^{-1}$ ) were measured three times using hand-held probes (WTW, Weilheim, Germany) in situ, in each of the sites and habitats. Three replicates of water samples were collected in each reach or habitat type for nutrient analyses (nitrogen nitrate $\left(\mathrm{N}^{-\mathrm{NO}_{3}}{ }^{-}, \mathrm{mg}\right.$ $\left.\mathrm{l}^{-1}\right)$, nitrogen nitrite $\left(\mathrm{N}_{-} \mathrm{NO}_{2}{ }^{-}, \mathrm{mg} \mathrm{l}^{-1}\right)$, nitrogen ammonium $\left(\mathrm{N}^{-\mathrm{NH}_{4}}{ }^{+}, \mathrm{mg} \mathrm{l}^{-1}\right)$, dissolved organic carbon analysis (DOC, $\mathrm{mg} \mathrm{l}^{-1}$ ) and cation and anion analyses $\left(\mathrm{Na}^{+}, \mathrm{K}^{+}, \mathrm{Mg}^{2+}, \mathrm{Ca}^{2+}, \mathrm{Cl}^{-} \mathrm{mg} \mathrm{l}^{-1}\right)$ ). Once collected, water samples were filtered using $0.7 \mu \mathrm{m}$ GF/F filters (Whatman Int. Ltd., Maidstone, UK) and kept at $-20^{\circ} \mathrm{C}$ until analysis. Nitrite, nitrate, ammonium and cations concentrations were determined on a Dionex ICS-5000 ion chromatograph (Dionex Co., Sunnyvale, USA; Hach Company, 2002). DOC concentration was determined on a Shimadzu TOC-V CSH coupled to a TNM-1 module (Shimadzu Co., Kyoto, Japan). Detection limits for nutrient analyses were set at $0.004 \mathrm{mg} \mathrm{N}-\mathrm{NO}_{2}{ }^{-} 1^{-1}$ for nitrogen nitrite, $0.023 \mathrm{mg} \mathrm{N}-\mathrm{NO}_{3}{ }^{-} \mathrm{1}^{-1}$ for nitrogen nitrate and $0.01 \mathrm{mg} \mathrm{N}-\mathrm{NH}_{4} \mathrm{1}^{-1}$ for nitrogen ammonium.

\section{Biofilm identification}

Three to four cobbles were randomly collected within a $3 \mathrm{~m}$ area along each transect or habitat studied. Biofilms were scraped off from cobbles, placed in plastic tubes containing unfiltered stream water, and preserved with 4 drops of $39 \%$ formaldehyde ( $4 \%$ final concentration). Unfiltered stream waters in shallow systems have a negligible contribution of drifting or planktonic taxa.

Analysis and identification of the phototrophic biofilm community was performed using microscopical examination at 400x (Nikon Eclipse E200, Tokyo, Japan). The analysis of the relative abundance of algae and cyanobacteria followed a sequential approach. First, the whole sample was placed in a petri dish; patches, if any, were selected and separately identified at the microscope. After all observations were completed, a weighted average of the relative abundance of algae and cyanobacteria genera was produced for each replicate. We used relative abundances instead of raw count cells to account for the uncertainty associated to the large presence of colonial cyanobacteria in many of the sites. The relative abundance of each taxonomical entity (mostly genus) was ranked by applying the following scale: 1 (very rare, $\leq 5 \%$ ), 2 $(>5$ to $\leq 20 \%), 3(>20$ to $\leq .40 \%), 4$ ( $>40$ to $\leq$ $60 \%), 5$ ( $>60$ to $\leq 80 \%$ ) and 6 (very abundant, $\geq$ $80 \%$ ). We used these categories in the subsequent statistical analyses, and as a compromise between the presence-absence counting and the impossibility to reliably consider the abundances of the genera present in the sample. Once taxonomical identifications were finished, the phototrophic biofilm genera were assigned to 6 traits categories, encompassing a total of 21 traits following Lange et al. (2016) ("Appendix A", Tables 1 to 2 ).

\section{Statistical analysis}

An abundance matrix including all genera with at least one occurrence within the category 3 ( $>20$ to $\leq$ $40 \%$ ) resulted in a total of 31 taxa determined at the network scale, and 18 taxa determined at the habitat scale. The ordination of phototrophic biofilms in the samples was performed by means of a Principal Components Analysis (PCA) using the Spearman rank coefficient in a covariance matrix. Analyses were performed using the "princomp" function of the "stats" and the "factorextra" packages (Team \& Worldwide, 2002; Kassambara \& Mundt, 2017) in R software version 3.3.0 ( $\mathrm{R}$ Core Team, 2017). The influence of the environmental variables on the distribution of the algal communities was investigated by means of a distance-based redundancy analysis (dbRDA) using Bray-Curtis dissimilarity distances. This was performed using the "capscale" function of the "vegan" package in Rstudio (Oksanen et al., 2013). The db-RDA analysis was run only with environmental variables that had no collinearity between them and that meaningfully explained the distribution of the taxa.

A biofilm traits matrix was elaborated by multiplying the matrix of genera abundances by the matrix of assigned trait categories for each genus, using the "base" package in Rstudio. Trait categories had been 
previously converted to dummy variables. Subsequently, the spatial variability of traits was explored with a non-Metric MultiDimensional Scaling analysis (nMDS) using the "metaMDS" function. nMDS analysis was performed using a Bray-Curtis distance, Wisconsin double standardization and $k=2$ dimensions. Clusters grouping rivers and local habitat types were shown using the "ordiellipse" function of the "vegan" package.

Finally, alpha, and beta (expressed as the Jaccard index of dissimilarity) diversity were calculated on the taxonomical data using the "vegdist" and "specnumber" functions in the "vegan" package.

\section{Results}

Site characterization

\section{Network scale}

According to the dominant calcareous substrata water conductivity ranged between 265 and $587 \mu \mathrm{S} \mathrm{cm}^{-1}$ and $\mathrm{pH}$ between 8 and 9.2, higher values being recorded in the downstream A8 and A9 sites ("Appendix B", Table 3). Water temperature in February ranged between 7.2 and $12.1^{\circ} \mathrm{C}$, and dissolved oxygen

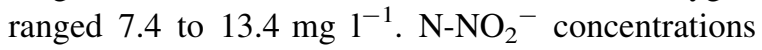
were nearly undetectable, while nitrogen nitrate concentrations were lower in the upstream sites (0.13-0.27 $\left.\mathrm{mg} \mathrm{N}^{-\mathrm{NO}_{3}}{ }^{-} \mathrm{l}^{-1}\right)$ and increased downstream up to a maximum of $7 \mathrm{mg} \mathrm{N}-\mathrm{NO}_{3}{ }^{-} \mathrm{1}^{-1}$ in the A5 site. $\mathrm{Na}^{+}, \mathrm{K}^{+}, \mathrm{Mg}^{2+}, \mathrm{Ca}^{2+}, \mathrm{Cl}^{-}$and DOC concentrations also showed an increasing trend further downstream in the Algars, peaking at A9 site, and a less pronounced downstream increase in the Estrets river (“Appendix B", Table 3).

\section{Habitat scale}

Conductivity was higher in site A9 (1470-1514 $\mu \mathrm{S}$ $\mathrm{cm}^{-1}$ ) than in site A3 $\left(524-536 \mu \mathrm{S} \mathrm{cm}^{-1}\right.$ ) (Appendix $\mathrm{B}$, Table 4). April water temperature in in the two sites ranged between $16-19.5^{\circ} \mathrm{C}$. $\mathrm{pH}$ values ranged between 7.5-8 and dissolved oxygen concentrations were between 7.4 to 9.3 for riffle habitats and between 5.2-7.7 for pool habitats. Nutrients and cations and anion concentrations were higher in the A9 site, including nitrogen nitrates $\left(4.8-5.3 \mathrm{mg} \mathrm{N}-\mathrm{NO}_{3}{ }^{-} 1^{-1}\right.$ and $0.050-0.135 \mathrm{mg} \mathrm{N}^{-\mathrm{NO}_{3}}{ }^{-} \mathrm{1}^{-1}$ in A3). DOC concentrations reached $1.47-2.2 \mathrm{mg} \mathrm{C}^{-1}$ in the A9 site and $0.987-1.44 \mathrm{mg} \mathrm{C}^{-1}$ in A3; differences were not observed between riffles and pools ("Appendix B", Table 4).

Phototrophic biofilm communities

\section{Network Scale}

Eighty-five taxa of algae and cyanobacteria were identified in the network sites, eight of them identified at a higher level than genus ("Appendix D", Tables 6 to 8). The mean number of taxa (alpha diversity) including all the sampling sites was 41.9, and the mean beta dissimilarity between sites was 0.71 ("Appendix C", Table 5). In the Algars sites, diatoms (mostly Cymbella and Fragilaria) were abundant in A1, a site with the highest canopy cover, whereas in the forested headwaters of the Estrets (site E10) Cladophora was the most common (Fig. 2 and "Appendix D", Tables 6 to 8). Cyanobacteria dominated in the lower sites of the Algars (A6 to A9; and) and Estrets (E13 to E16) ("Appendix C", Fig. 8). The cyanobacteria Dichothrix and Rivularia formed encrusting communities scattered all over the network, mostly in open areas (such as sites A9 and E16, Fig. 2). The filamentous Cladophora and Audouinella were abundant in sites characterized by higher water velocity and moderate human pressure (mostly sites A4 and A5). The unattached filaments of Zygnema, Mougeotia and Spirogyra prevailed in sites with low water velocity throughout upper and middle parts of the two rivers (Fig. 2).

The $\beta$-diversity estimates indicated that the upstream sites were the most distinct to each other ( $\beta$-div 0.655), while sites in the middle part and lower part of the river were relatively alike ( $\beta$-div 0.495 and 0.496 , respectively). This contrasted to the higher $\alpha$ diversities from upstream (61 genera) to middle (62 genera) and downstream (79 genera) ("Appendix C", Table 5).

The first axis of the PCA analysis (PC1; eigenvalue $=6.617 ; 19.8 \%$ of the total variance; Fig. 2 ) separated the genera Cladophora and its epiphyte Cocconeis, dominant in sites A4, A5 and E10, from the cyanobacterial community of Scytonema and Dichothrix characteristic of sites A2, E13 and E14. The scores of sites A2, A3, A6, A9 and E10 occupied a 
Fig. 2 Results from the PCA analysis at the network scale for the phototrophic biofilm genera assemblage. The PCA axis 1 explains $19.8 \%$ of the variance found and the PCA axis 2 explains $12.1 \%$ of the variance. The abbreviations indicate the different sampling sites, including 9 sampling sites from the Algars river ('A') and 5 sites from the Estrets river ('E')

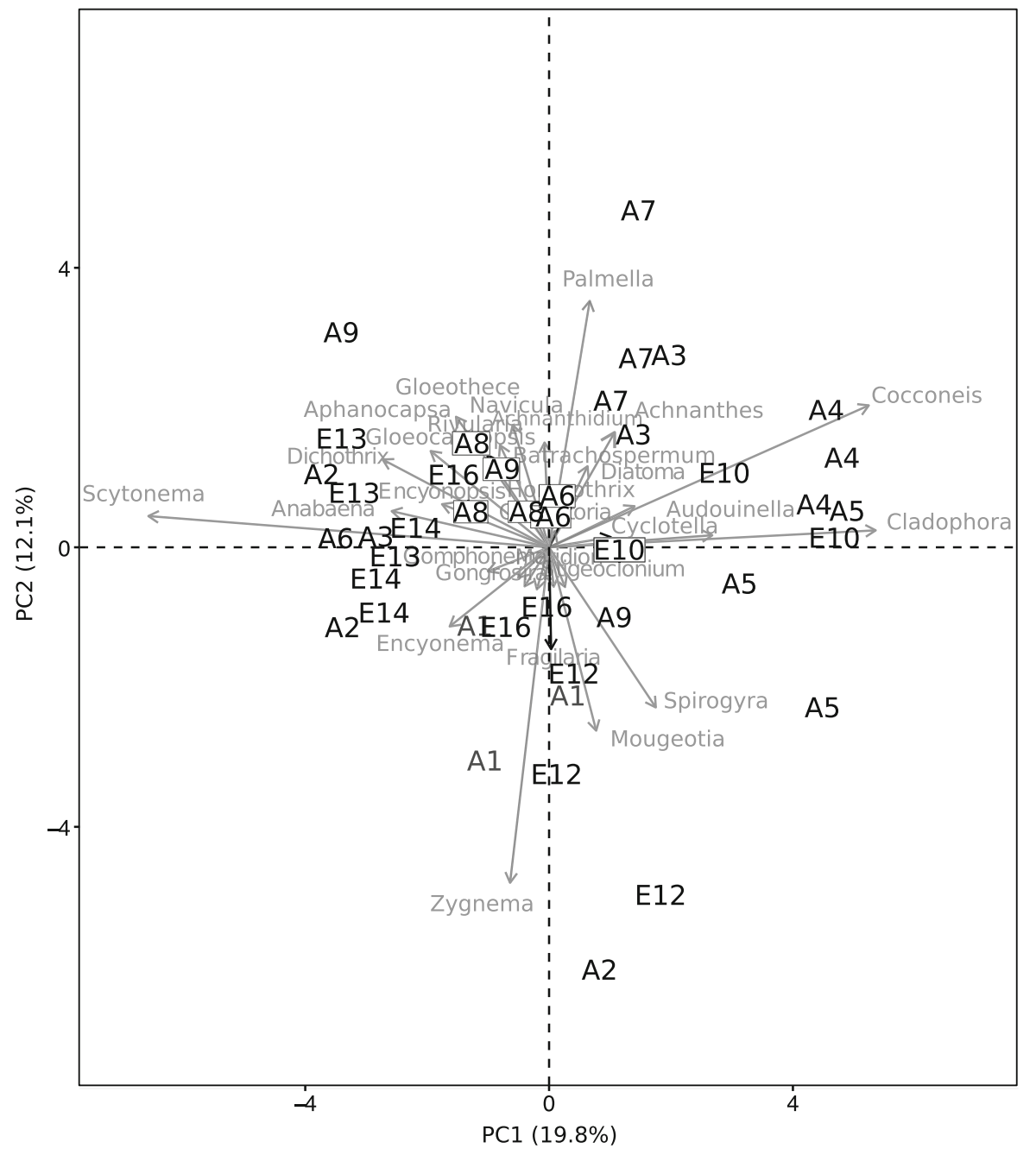

wide space on the first axis, revealing high within-site variability. Indeed, the $\beta$-diversity between the sites in the different sections of the river network enlarged when all replicates were considered ("Appendix C", Table 5). The second axis (PC2; eigenvalue $=4.029$; $12.1 \%$ of the total variance) separated the genera Palmella, Achnanthes and Gloeothece, abundant in sites A7 and A8, from Spirogyra, Mougeotia and Zygnema, prevalent in sites A1, A2 and E12. The scores of sites A2, A9 and E12 spanned through axis 2 and showed a large within-site variability.

The db-RDA analysis correlates the environmental variables with phototrophic biofilm genera (Fig. 3). The environmental variables that were selected by the $\mathrm{db}$-RDAs and accounted for the distribution of algae and cyanobacteria in the different sites were DOC, $\mathrm{N}-\mathrm{NO}_{3}{ }^{-}, \mathrm{N}_{-} \mathrm{NH}_{4}{ }^{+}, \mathrm{Mg}^{2+}$ and $\mathrm{Ca}^{2+}$ concentrations, as well as habitat type. The first axis (db-RDA1) separates phototrophic biofilm genera and associated sites in a similar manner to that shown by the first axis of the PCA analysis, separating A4, A5 and E10 to A2, E12, E13 and E14 sites. Axis 1 was correlated mainly with $\mathrm{N}_{-\mathrm{NO}_{3}}{ }^{-}$and $\mathrm{N}_{-} \mathrm{NH}_{4}{ }^{+}$(eigenvalue $=0.2687$; $25.4 \%$ of the total variance), and relate them with the occurrence of Cladophora, Cocconeis and Audouinella. The second axis (db-RDA2; eigenvalue $=0.1490 ; 14.1 \%$ of the total variance) was correlated mainly with DOC concentration and separated site E12 dominated by Zygnema from Dichothrix and Rivularia from sites A7 and A8 (Fig. 3).

Finally, for the analysis of the genera traits, nMDS analysis (stress $=0.179$, Fig. 4) displayed a wide variety of traits present within several sites (A2, A5, A6, A7, A8, A9, E10 and E12). This was shown by the 


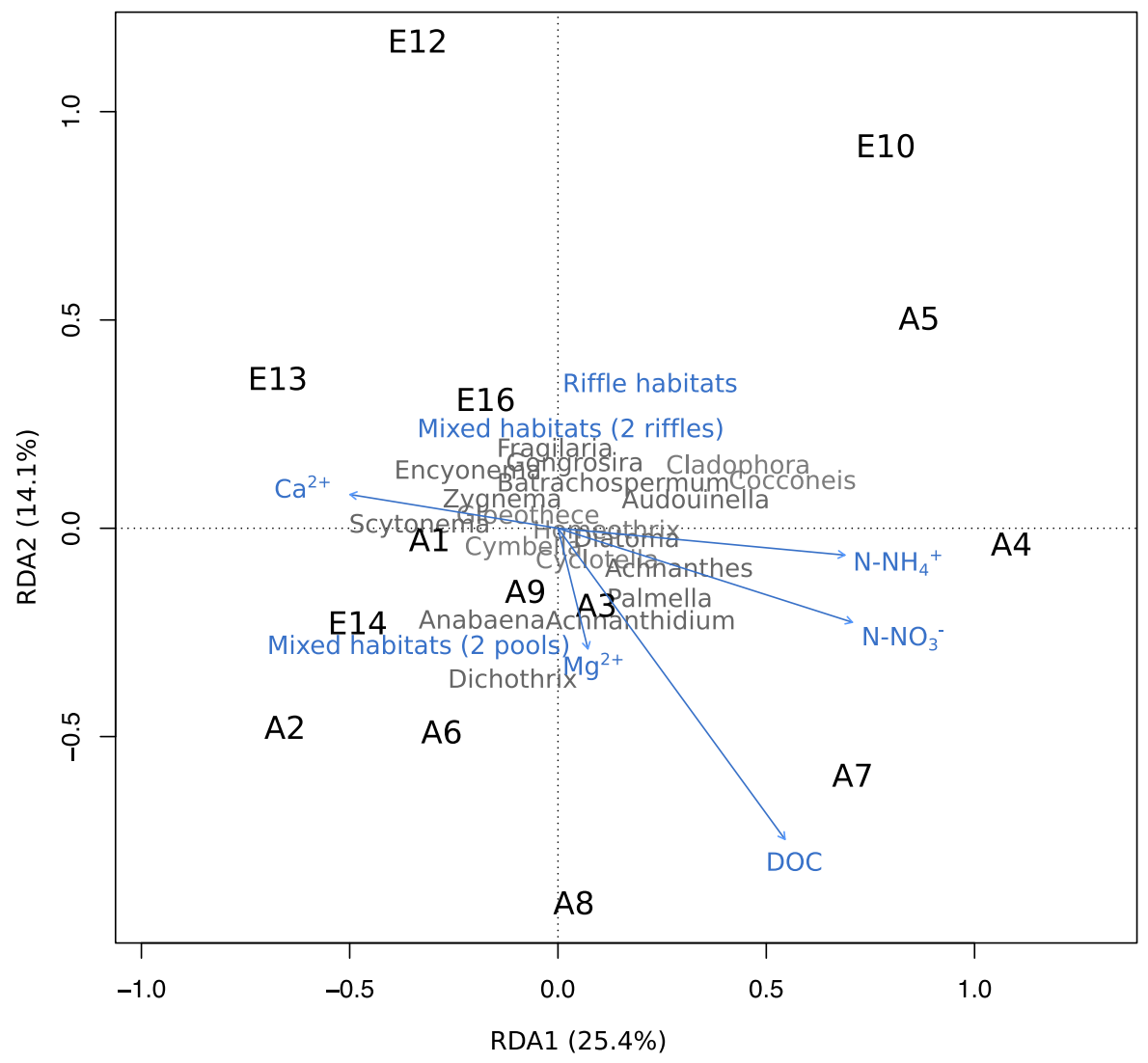

Fig. 3 Results from the db-RDA analysis at the network scale including phototrophic biofilm genera and environmental variables. The db-RDA axis 1 explains $25.4 \%$ of the variance and db-RDA axis 2 explains $14.1 \%$ of the variance. Phototrophic biofilm genera are displayed in grey and sampling sites are displayed in black, including 9 sampling sites from the

distance between the replicates of the sites (Fig. 4). The trait "high attachment" was characterized by site A4, "low attachment" for site A1 and "nitrogen fixation" and "colonial life form" for site A7. Sites E13 and E14 were characterized by the trait "medium attachment" (“Appendix A", Table 2).

\section{Habitat scale}

At the local habitat scale, a total of 93 phototrophic biofilm genera were identified in A3 and A9, including 13 undetermined genera ("Appendix D", Tables 9 to 10), during the corresponding sampling. Assemblages' composition varied according to the sites, as well as according to the habitats and even the replicates ("Appendix C", Fig. 9). For example, the three riffle habitats of site A3 were correspondingly
Algars river ('A') and 5 sites from the Estrets river (' $E$ '). The blue arrows indicate the included environmental variables $(\mathrm{N}$ $\mathrm{NO}_{3}{ }^{-}, \mathrm{N}-\mathrm{NH}_{4}{ }^{+}$, Magnesium $\left(\mathrm{Mg}^{2+}\right)$, Calcium $\left(\mathrm{Ca}^{2+}\right)$ and DOC concentrations and habitat type (mixed habitats with 2 pools, mixed habitats with 2 riffles, riffle habitats)

inhabited by red algae (first riffle), diatoms (second riffle) or cyanobacteria (third riffle). Green algae and diatoms dominated the two pool habitats of site A3. The three riffle habitats of site A9 were abundant in cyanobacteria and diatoms. Pool habitats of site A9 recorded dominances in green algae (first pool) or cyanobacteria (second pool).

Of the 93 identified phototrophic biofilm genera, 80 were found in pool sites and 82 in riffle sites, with 12 genera exclusive to pools, and 11 exclusives to riffles. The average alpha diversity of habitats was 50.4, with a mean number of 51.5 genera in pools and 49.7 genera present in riffles ("Appendix C", Table 5). The average dissimilarity ( $\beta$-diversity) in both sites A3 and A9 was lower between pools $(0.29-0.33)$ than between riffles (0.42-0.43). 


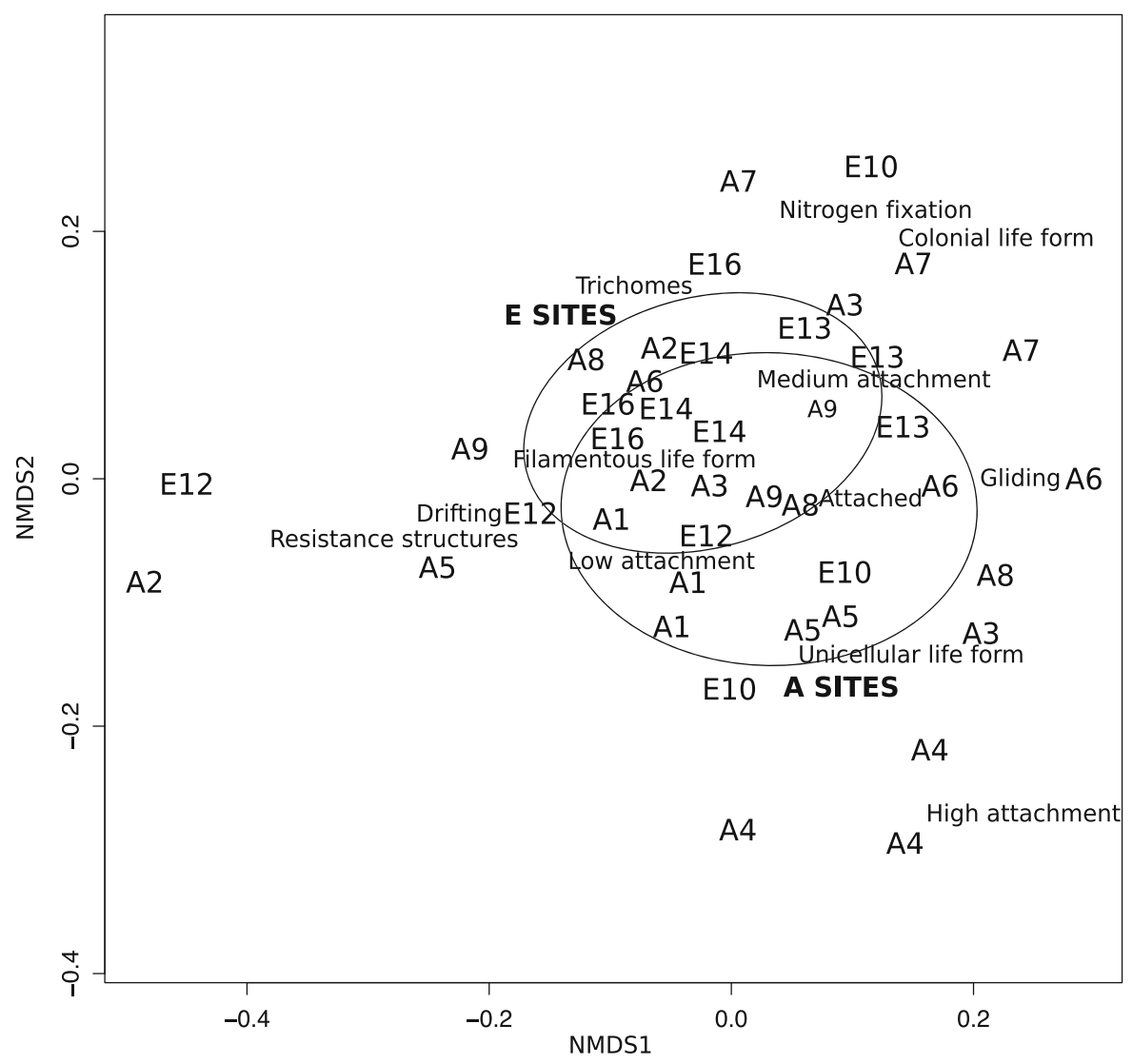

Fig. 4 Results from the nMDS analysis at the network scale. The abbreviations indicate the different sampling sites, including 9 sampling sites from the Algars river ('A') and 5 sites from

The PCA analysis performed with the habitats separated the A3 riffle habitats from the A3 pool habitats and all the other habitat types from A9 $(62.4 \%$ of total variance; Fig. 5). The first axis (PC1; eigenvalue $=3.963 ; 24.7 \%$ of the total variance) separated the genera Rivularia, Schizothrix, Dichothrix and Zygnema from Palmella, and A9 samples from A3 samples. Palmella was abundant in pool habitats from A3 and coexisted with Gloeocapsa or Zygnema in in riffle habitats with low water velocity. The second axis (PC2; eigenvalue $=2.319 ; 14.5 \%$ of the total variance) separated the genera Chaetophora, Batrachospermum and Schizothrix from Palmella and Zygnema, and the A3 riffles from the other habitats. Sites with higher flow velocity (i.e. riffle sites, $\mathrm{R}$ sites) were abundant in diatoms such as Gomphomena, Cymbella, or Navicula, cyanobacteria such as Calothrix, Schizothrix or Dichothrix, green alga like Chaetophora, and red alga like Batrachospermum (Fig. 5). Habitats with the Estrets river ('E'). The clusters indicate the different sampling sites from each river (A and $\mathrm{E}$ )

high light availability (such as A9P2, A9R1-3) favoured the occurrence of Rivularia and Dichothrix, while the red alga Batrachospermum dominated in shady habitats (such as A3R1, A3R3). The environmental variables that were selected by the db-RDAs and accounted for the distribution of algae and cyanobacteria in the different habitats and sites, were DOC, nitrate, $\mathrm{Ca}^{2+}$ and dissolved oxygen concentration (Fig. 6). The RDA analysis showed a strong correlation of site $\mathrm{A} 9$ samples with $\mathrm{N}-\mathrm{NO}_{3}{ }^{-}, \mathrm{Ca}^{2+}$ and DOC concentrations (first axis; eigenvalue $=0.2450$; $29.3 \%$ of the total variance) (Fig. 6). The second axis (eigenvalue $=0.176 ; 21 \%$ of the total variance) was correlated mainly with dissolved oxygen concentrations (DO) and separated the pool and riffle habitats of site A3. Pool and riffle habitats from site A9 were also separated, but to a lesser extent. Most phototrophic biofilm genera were clustered around the centre. 
Fig. 5 Results from the PCA analysis for the phototrophic biofilm genera assemblage at the habitat scale. PCA axis 1 explains $24.7 \%$ of the variance found and PCA axis 2 explains $14.5 \%$ of the variance. The abbreviations indicate the different habitat types, including 2 pool habitats from site A3 (A3P1, A3P2), 3 riffle habitats from site $\mathrm{A} 3$ (A3R1, A3R2, A3R3), 2 pool habitats from site A9 (A9P1, A9P2) and 3 riffle habitats from site A9 (A9R1, A9R2, A9R3)

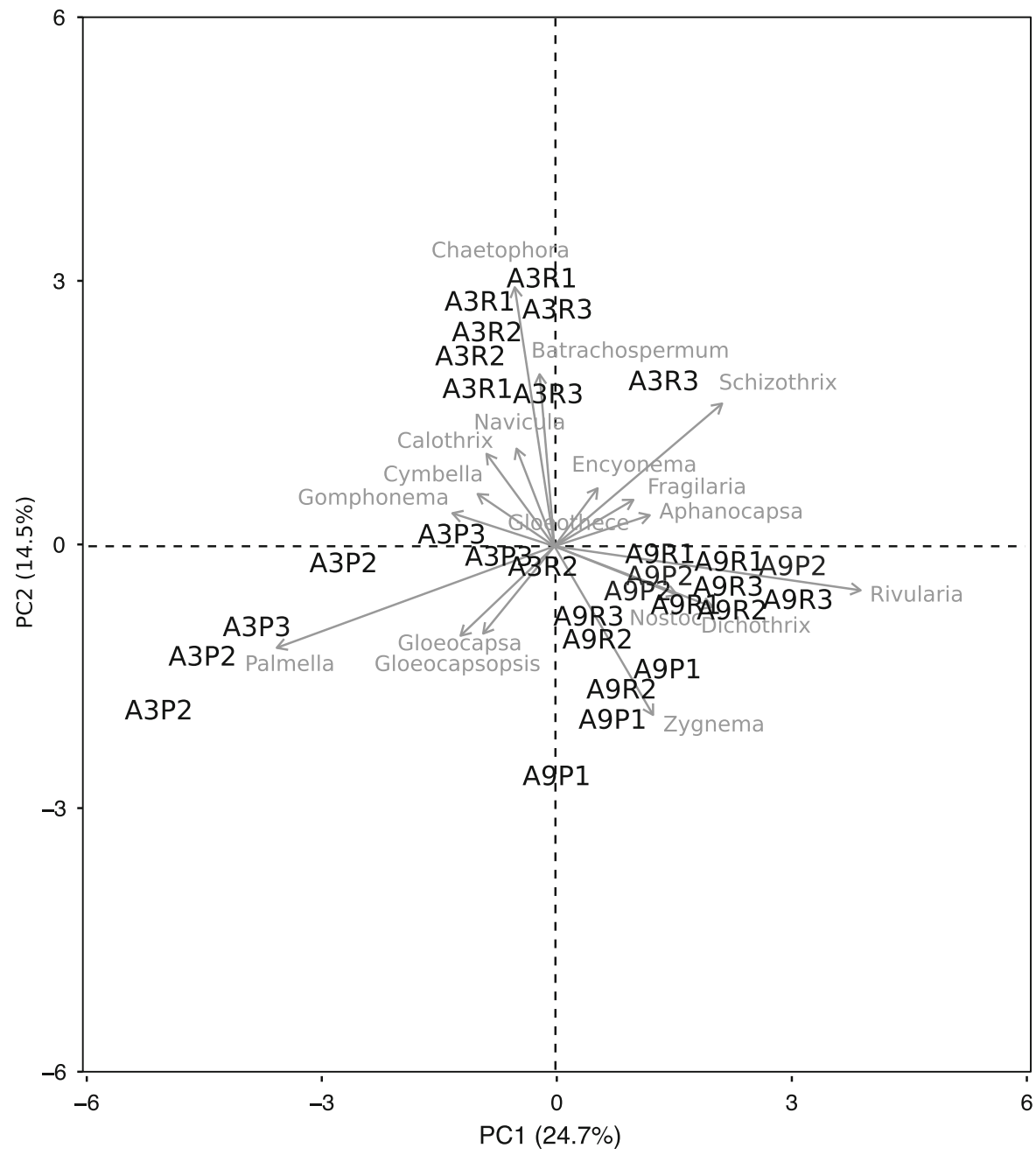

The nMDS analysis (stress $=0.137$, Fig. 7) clustered riffle habitats from site A3 and A9 associated with the traits "unicellular life form", "medium attachment", "attached" and "nitrogen fixation". Pool habitats from site A3 were associated with the traits "colonial life form" and "drifting", while the first pool from A9 had taxa characterized by "drift" and "low attachment" and the second pool was linked with the traits "filamentous life form" and "resistance structures" (Fig. 7).

\section{Discussion}

Phototrophic biofilm assemblages changed in composition and abundance driven by the local conditions of conductivity, nutrients, DOC and cation concentrations, which accentuated their differences downstream probably favoured by the base-flow conditions during the sampling. The local conditions of high nitrate and DOC, and the non-limiting light availability in the downstream sites, contrasted with the poor nutrient concentrations, shaded conditions and higher water velocities in the upstream sites. Replicates within the sites showed high variability in composition, reflecting a large within-site environmental variability. This was confirmed through the detailed analysis at the habitat scale in two of the sites, in a subsequent period with higher hydrological fragmentation. 


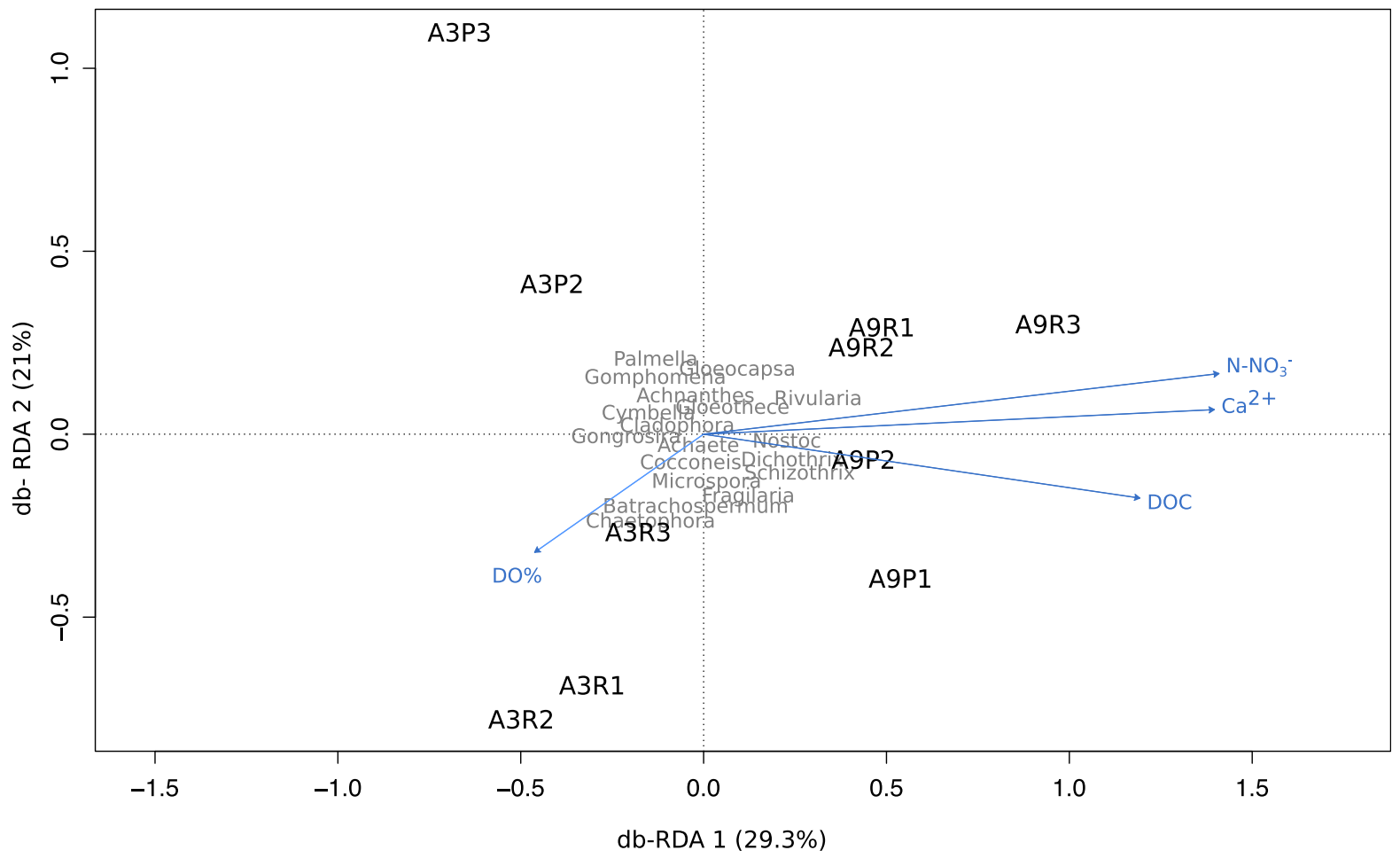

Fig. 6 Results from the db-RDA analysis including phototrophic biofilm genera at the habitat scale. The db-RDA axis 1 explains $29.3 \%$ of the variance and the db-RDA axis 2 explains $21 \%$ of the variance. Phototrophic biofilm genera are displayed in grey. The different symbols and colours display the different habitat types, including 2 pool habitats from site A3

\section{Network scale}

At the network scale, local conditions of nitrate, ammonium and DOC concentrations were identified by the $\mathrm{db}$-RDA as the major drivers of the structure of phototrophic biofilm assemblages. Nitrogen-fixing Scytonema was abundant at the upstream sites A2, E13 and E14, which had low nitrogen concentrations. The occurrence of nitrogen-fixing cyanobacteria is negatively correlated to the availability of nitrate (Porter et al., 2008; Stancheva et al., 2012). However, in the downstream Algars sites (A6, A8, A9) the nitrogen-fixing cyanobacteria Gloeothece, Rivularia and Dichothrix massively covered the riffle sections, likely as result of the strong nitrogen demand (as well as of their extensive cover of the streambed), and despite the relatively high nitrate concentrations. Even though we could not attribute the DOC presence to human or natural origin, higher DOC concentration in the sites with massive cover of nitrogen-fixing
(A3P1, A3P2), 3 riffle habitats from site A3 (A3R1, A3R2, A3R3), 2 pool habitats from site A9 (A9P1, A9P2) and 3 riffle habitats from site A9 (A9R1, A9R2, A9R3). The blue arrows indicate the included environmental variables $\left(\mathrm{N}_{-} \mathrm{NO}_{3}{ }^{-}, \mathrm{Ca}^{2+}\right.$, DOC and DO\% (dissolved oxygen concentration))

Dichothrix might be a direct or indirect product of their abundance (Brauer et al., 2015).

Further downstream (sites A4, A5 and E10), Cladophora mats prevailed, also probably as a response to the higher nitrate levels (Penick et al., 2012) in those sites. Cladophora mats in site A5 (and others) were heavily colonized by the epiphytic diatom Cocconeis and other epiphytes (Bellinger \& Sigee, 2010). The abundance of grazers (Gastropoda) on the epiphytes probably favoured Cladophora since itself is highly resistant to grazing (Dodds \& Gudder, 1992; Bellinger \& Sigee, 2010), while epiphytes are a cause of decay for the alga (Whitton, 1970). Cladophora could also take advantage of high water velocity (Biggs, 1996; Tornés \& Sabater, 2010), which together with nutrients, provided with an advantage over nitrogen-fixing cyanobacteria, and account for its abundance on riffle habitats.

Upstream sites with lower DOC concentrations and higher canopy cover (A1, A2, and Estrets river sites) 


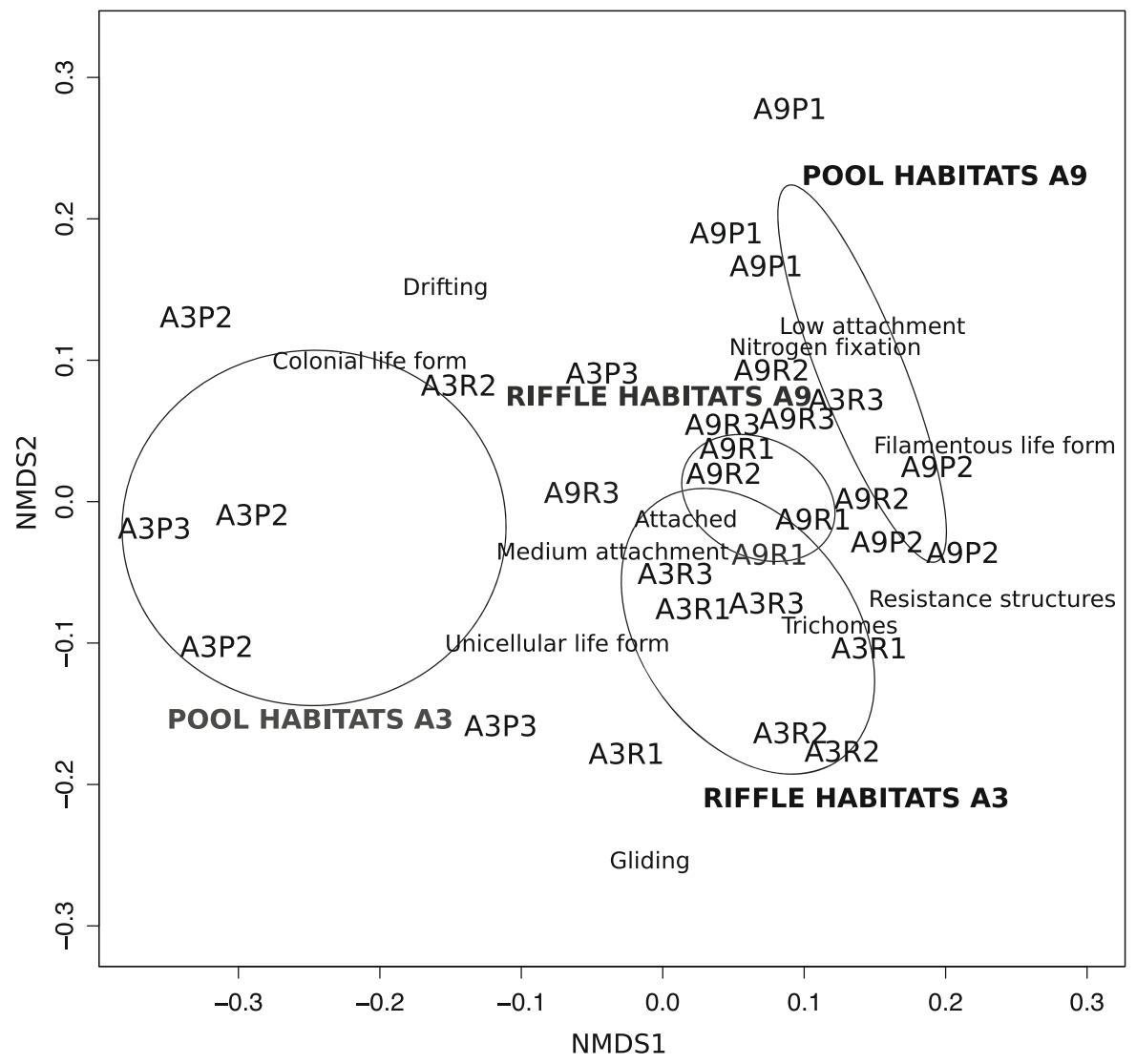

Fig. 7 Results from the nMDS analysis of the algal traits at the habitat scale. The abbreviations indicate the different habitat types, including 2 pool habitats from site A3 (A3P1, A3P2), 3 riffle habitats from site A3 (A3R1, A3R2, A3R3), 2 pool habitats from site A9 (A9P1, A9P2) and 3 riffle habitats from site A9 (A9R1, A9R2, A9R3). The clusters indicate the different habitats (pools and riffles) and sites (A3 and A9)

traits, and makes a practical point to perform a multihabitat sampling to account for it. For example, site E10 was dominated by Cladophora ("high attachment") in one transect, but by Gloeothece ("nitrogen-fixing") in other transects. Likewise, site A5 was abundant in Cladophora at one riffle, but inhabited by Spirogyra ("resistance structures") at another riffle. Restraining the sampling in routine monitoring to single locations (i.e. riffles) in temporary streams might lose a relevant fraction of diversity. Despite these variations, though, some patterns were consistent with the environmental changes throughout the network. Headwaters were dominated by "drifting algae" and "resistance structures". Further downstream, riffles had prevalence of "attached" forms, while the slowly flowing sites were abundant in "colonial", and "nitrogen-fixing" taxa. Our results 
confirmed that traits such as life form, nitrogen fixation ability, or spore formation capacity are individuals' responses to flow velocity and nitrogen concentration conditions, in the manner already suggested by Lange et al. (2016).

Both the taxonomical and trait approaches emphasized the role of water chemistry (i.e. nitrate, ammonium and DOC concentrations) and physical conditions (as water flow velocity) seen by the increase of green algae relative to cyanobacteria in the middle stream sites. Still, the within sites variability was mostly associated to local variations of water flow velocity and accounted for the large diversity of taxa as well for the heterogeneous trait distribution on each of the sites within the network. These findings emphasize the importance of longitudinal changes in water chemistry and physical conditions on prompting large changes in phototrophic biofilm assemblages.

\section{Habitat scale}

The detailed analysis of the phototrophic biofilm assemblages within two of the sites confirmed that habitats accounted for high differences which accentuated those already existing between the two sites (one more incised and nitrate-poor A3, the other wide open and nitrate-rich, A9). Pools showed lower dissolved oxygen concentrations than riffles, particularly in site A3 because of their higher hydrological disconnection. During the hydrological disconnection pools become small lentic waterbodies and may host a specific assemblage of loosely attached taxa (Passy 2007). Previous research suggests that pools can sustain higher species richness than riffles (Müllner \& Schagerl, 2003; Potapova \& Charles, 2005). Furthermore, their composition was more homogeneous to each other (lower $\beta$-diversity) than in the case of riffles, as also was observed in our detailed study.

The phototrophic biofilm assemblages in the riffle habitats of sites A3 and A9 had different taxonomical composition, but similar traits. Most taxa were tightly attached, and filamentous forms with trichomes and/or the ability for nitrogen fixation prevailed. In the second sampling campaign, when the two sites had low flow conditions and moderate nutrient concentrations, filamentous mats and nitrogen-fixing cyanobacteria could be favoured (Fairchild \& Lowe, 1984; Fairchild et al., 1985; Peterson \& Grimm, 1992; Sabater et al., 2008). Masses of Chaetophora and
Batrachospermum in site A3 could appear as a response to phosphate limitation (Gibson \& Whitton, 1987). Also, the tube-forming diatom Encyonema and the stalk-forming diatoms Cymbella and Gomphomena were abundant in riffle habitats of A3, likely favoured by the open flow and abundant light conditions (Rimet \& Bouchez, 2012; Béres et al., 2017). Rivularia and Dichothrix were dominant in the riffle habitats of site A9, forming "crust-forming" colonies which are able to resist desiccation (Sabater, 2000; Timoner et al., 2014). They possess a high ability to recover its activity after flow return (Romani \& Sabater, 1997). Also the mucilaginous colonies of Nostoc in site A9 might be understood as a protective structure to desiccation stress (Stanley et al., 2004; Fleming \& Castenholz, 2007). Overall, the compositional differences between sites A3 and A9 was probably related to their hydrological conditions, site A9 being more prone to flow intermittency and habitat fragmentation than those in A3, which had a lower annual flow variability and remained permanent. Mucilage-forming taxa were less common in site A3, likely because this protective structure was not so much necessary (i.e. desiccation events).

Contrary to the differences between sites, the taxonomic composition in site A9 between pools and riffles was similar, but traits associated to the habitat types, based on all taxa present, were different. However, in site A3 both the taxonomic and trait composition were pronouncedly different between riffles and pools. This site had a more constrained channel than A9, this facilitating higher habitat fragmentation and distinct hydrological conditions between habitats under low flow (Ledger et al., 2008). Though the number of days of the hydrological disconnection between the different habitats was unknown, it was sufficient to allow strong biogeochemical differences between them (Fazi et al., 2013). The phototrophic biofilm assemblages present in the A3 pools were mostly unicellular or colonial life forms, probably accounting for a strategy of enhancing nutrient uptake because small sized algae and cyanobacteria have higher surface area to volume ratio which allows them to be more efficient (Chisholm, 1992). Small cell sizes have been also proposed as an adaptation to stream drying because it allows cells shifting into deeper layers of the biofilm or being preserved between substratum particles (Lange et al., 2016). The taxa present in the site A9 pools had 
the ability to construct resistance structures to drought (Sabater, 2000; Romaní et al., 2013). Amongst them, Zygnema filaments are able to produce resting spores (Romaní et al., 2013) and its traits "low attachment" and "drifting" allow it to allocate nutrients in the water column (Lange et al., 2016). The variety of traits associated with the genera in the pool habitats may have been driven by a combination of low nutrient concentrations and drying conditions (Biggs \& Smith, 2002; Fazi et al., 2013).

Overall, the spatial heterogeneity associated with habitat fragmentation was a major driver of the metacommunity structure in the two sites (Passy, 2001; Huey et al., 2011). Alpha diversity was higher during the hydrological fragmentation (i.e. low flow conditions) than during the base-flow hydrological conditions. It might be considered, though, that the time elapsed between the two samplings could have influenced these results (Tornés and Sabater, 2010). As an example, several taxa absent in site A3 or in site A9 in winter (February) became dominant in spring (April). For example, Zygnema appeared in the first pool of A9, Gomphomena in the pools of site A3 and Chaetophora in the riffles of site A3. Overall, site A9 was characterized by an increase of cyanobacteria and a decrease of diatoms, a common pattern under drying conditions (Romani et al., 1998; Rothrock \& GarciaPichel, 2005; Pohlon et al., 2013). Beyond the comparison between the two samplings, hydrological disconnection led to lower beta diversity, mostly in the pools, which were often dominated by a single taxon. Previous research found similar changes in diatom communities during increased habitat fragmentation (Tornés \& Ruhí, 2013).

\section{Concluding remarks}

The drying and warming of Mediterranean streams (Giorgi \& Lionello, 2008; Acuña et al., 2017) alter the connectivity and habitat persistence (Huey et al., 2011). Our results show that nitrate and DOC concentrations were the major drivers on the phototrophic biofilm communities during base-flow conditions at the network scale. Additionally, the smallscaled spatial heterogeneity of phototrophic biofilm communities prevailed during hydrological disconnection where algal communities from pools and riffles clearly differ. It might be assumed that changes in phototrophic biofilm communities and adaptation strategies can be expected in response to the predicted increase in extreme weather events and overall drying and warming of Mediterranean temporary streams.

Acknowledgments This research was co-funded by the Erasmus + programme of the European Union (to NV). The research was funded by the projects CLIMALERT (PCIN-2017068) and SPACESTREAM (CGL2017-88640-C2-1-R) of the Spanish Ministry of Science and Innovation. ICRA is part of the CERCA programme. Anna Freixa acknowledges the Juan de la Cierva program (FJCI-2017-33171). This work, conducted at ICRA, was also the research by N.H.W. in the Master's Program in Freshwater \& Marine Biology at the University of Amsterdam.

Open Access This article is licensed under a Creative Commons Attribution 4.0 International License, which permits use, sharing, adaptation, distribution and reproduction in any medium or format, as long as you give appropriate credit to the original author(s) and the source, provide a link to the Creative Commons licence, and indicate if changes were made. The images or other third party material in this article are included in the article's Creative Commons licence, unless indicated otherwise in a credit line to the material. If material is not included in the article's Creative Commons licence and your intended use is not permitted by statutory regulation or exceeds the permitted use, you will need to obtain permission directly from the copyright holder. To view a copy of this licence, visit http://creativecommons.org/licenses/by/4.0/.

\section{References}

Aboal, M., 1988. Zygnemataceae (Conjugales, Chlorophyceae) of the river Segura basin, southeastern Spain. Nova Hedwigia 47: 389-402.

Acuña, V., I. Muñoz, A. Giorgi, M. Omella, F. Sabater \& S. Sabater, 2005. Drought and postdrought recovery cycles in an intermittent Mediterranean stream: structural and functional aspects. Journal of the North American Benthological Society 24: 919-933.

Acuña, V., M. Hunter \& A. Ruhí, 2017. Managing temporary streams and rivers as unique rather than second-class ecosystems. Biological Conservation 211: 12-19.

Battin, T. J., K. Besemer, M. M. Bengtsson, A. M. Romani \& A. I. Packmann, 2016. The ecology and biogeochemistry of stream biofilms. Nature Reviews. Microbiology 14: 251-263.

Bellinger, E. G. \& D. C. Sigee, 2010. Algae as bioindicators. Freshwater algae: identification and use as bioindicators. Wiley, Chichester: 99-136.

Béres, B., V. P. Török, Z. Kókai, Á. Lukács, E. T. Krasznai, B. Tóthmérész \& I. Bácsi, 2017. Ecological background of diatom functional groups: comparability of classification systems. Ecological Indicators 82: 183-188.

Biggs, B. J. F., 1996. Patterns in Benthic algae of streams. In Stevenson, R. J., M. L. Bothwell \& R. L. Lowe (eds.), Algal 
ecology. Freshwater benthic ecosystems. Academic Press, New York.

Biggs, B. J. F. \& R. A. Smith, 2002. Taxonomic richness of stream benthic algae: effects of flood disturbance and nutrients. Limnology and Oceanography 47: 1175-1186.

Boithias, L., V. Acuña, L. Vergoñós, G. Ziv, R. Marcé \& S. Sabater, 2014. Assessment of the water supply: demand ratios in a Mediterranean basin under different global change scenarios and mitigation alternatives. Science of the Total Environment 470-471: 567-577.

Bonada, N., \& V. H. Resh, 2013. Mediterranean-climate streams and rivers: Geographically separated but ecologically comparable freshwater systems. Hydrobiologia 719: 1-29.

Bott, T. L. \& L. A. Kaplan, 1990. Potential for protozoan grazing of bacteria in streambed sediments. Journal of the North American Benthological Society 9: 336-345.

Brauer, V. S., M. Stomp, T. Bouvier, E. Fouilland, C. Leboulanger, V. Confurius-Guns, F. J. Weissing, L. Stal \& J. Huisman, 2015. Competition and facilitation between the marine nitrogen-fixing cyanobacterium Cyanothece and its associated bacterial community. Frontiers in Microbiology 5: $1-14$.

Chisholm, S. W., 1992. Phytoplankton size. In Falkowski, P. \& A. Woodhead (eds.), Primary productivity and biogeochemical cycles ins the sea. Springer, Berlin: 213-237.

Dodds, W. K. \& D. A. Gudder, 1992. The ecology of Cladophora. Journal of Phycology 28: 415-427.

Fairchild, G. W. \& R. L. Lowe, 1984. Artificial substrates which release nutrients: effects on periphyton and invertebrate succession. Hydrobiologia 114: 29-37.

Fairchild, G. W., R. L. Lowe \& W. B. Richardson, 1985. Algal periphyton growth on nutrient-diffusing substrates: an in situ bioassay. Ecology 66: 465-472.

Fazi, S., E. Vázquez, E. O. Casamayor, S. Amalfitano \& A. Butturini, 2013. Stream hydrological fragmentation drives bacterioplankton community composition. PLoS ONE 8: e60109.

Fleming, E. D. \& R. W. Castenholz, 2007. Effects of periodic desiccation on the synthesis of the UV-screening compound, scytonemin, in cyanobacteria. Environmental Microbiology 9: 1448-1455.

Gasith, A. \& V. H. Resh, 1999. Streams in Mediterranean climate regions: abiotic influences and biotic responses to predictable seasonal events. Annual Review of Ecology and Systematics 30: 51-81.

Gibson, M. T. \& B. A. Whitton, 1987. Hairs, phosphatase activity and environmental chemistry in stigeoclonium, chaetophora and draparnaldia (Chaetophorales). British Phycological Journal 22: 11-22.

Giorgi, F. \& P. Lionello, 2008. Climate change projections for the Mediterranean region. Global and Planetary Change 63: 90-104.

Graba, M., S. Sauvage, F. Y. Moulin, G. Urrea, S. Sabater \& J. M. Sanchez-Pérez, 2013. Interaction between local hydrodynamics and algal community in epilithic biofilm. Water Research 47: 2153-2163.

Huey, J. A., D. J. Schmidt, S. R. Balcombe, J. C. Marshall \& J. M. Hughes, 2011. High gene flow and metapopulation dynamics detected for three species in a dryland river system. Freshwater Biology 56: 2378-2390.
Kassambara, A., \& F. Mundt, 2017. Package 'factoextra.' Extract and visualize the results of multivariate data analyses 76.

Kelly, M., 2012. The semiotics of slime: visual representation of phytobenthos as an aid to understanding ecological status. Freshwater Reviews 5: 105-120.

Lange, K., A. Liess, J. J. Piggott, C. R. Townsend \& C. D. Matthaei, 2011. Light, nutrients and grazing interact to determine stream diatom community composition and functional group structure. Freshwater Biology 56: 264-278.

Lange, K., C. R. Townsend \& C. D. Matthaei, 2016. A traitbased framework for stream algal communities. Ecology and Evolution 6: 23-36.

Larned, S. T., T. Datry, D. B. Arscott \& K. Tockner, 2010. Emerging concepts in temporary-river ecology. Freshwater Biology 55: 717-738.

Ledger, M. E., R. M. L. Harris, P. D. Armitage \& A. M. Milner, 2008. Disturbance frequency influences patch dynamics in stream benthic algal communities. Oecologia 155: 809-819.

Leland, H. V. \& S. D. Porter, 2000. Distribution of benthic algae in the upper Illinois River basin in relation to geology and land use. Freshwater Biology 44: 279-301.

Lock, M. A., 1993. Attached microbial communities in streams. Aquatic microbiology: an ecological approach. Blackwell, Oxford: 113-138.

Lock, M. A., R. R. Wallace, J. W. Costerton, R. M. Ventullo, \& S. E. Charlton, 1984. River epilithon: toward a structuralfunctional model. Oikos JSTOR 10-22.

Lukács, Á., Z. Kókai, P. Török, I. Bácsi, G. Borics, G. Várbíró, E. T. Krasznai, B. Tóthmérész \& V. B. Béres, 2018. Colonisation processes in benthic algal communities are well reflected by functional groups. Hydrobiologia 823: 231-245.

Lukavsky, J., A. Moravcová, L. Nedbalová \& O. Rauch, 2006. Phytobenthos and water quality of mountain streams in the Bohemian Forest under the influence of recreational activity. Biologia Versita 61: S533-S542.

Matthaei, C. D., C. Guggelberger \& H. Huber, 2003. Local disturbance history affects patchiness of benthic river algae. Freshwater Biology 48: 1514-1526.

McAbendroth, L., P. M. Ramsay, A. Foggo, S. D. Rundle \& D. T. Bilton, 2005. Does macrophyte fractal complexity drive invertebrate diversity, biomass and body size distributions? Oikos 111: 279-290.

Müllner, A. N. \& M. Schagerl, 2003. Abundance and vertical distribution of the phytobenthic community within a pool and riffle sequence of an alpine gravel stream. International Review of Hydrobiology 88: 243-254.

Myers, N., R. A. Mittermeier, C. G. Mittermeier, G. A. B. Da Fonseca \& J. Kent, 2000. Biodiversity hotspots for conservation priorities. Nature 403: 853.

Oksanen, J., F. G. Blanchet, R. Kindt, P. Legendre, P. R. Minchin, R. B. O'hara, G. L. Simpson, M. H. H. Stevens \& H. Wagner, 2013. Package 'vegan'. Community ecology package, version 2: 1-295.

Passy, S. I., 2001. Spatial paradigms of lotic diatom distribution: a landscape ecology perspective. Journal of Phycology 37: 370-378. 
Passy, S. I., 2007. Diatom ecological guilds display distinct and predictable behavior along nutrient and disturbance gradients in running waters. Aquatic Botany 86: 171-178

Penick, M. D., S. A. Grubbs \& A. J. Meier, 2012. Algal biomass accrual in relation to nutrient availability and limitation along a longitudinal gradient of a karst riverine system. International Aquatic Research 4: 1-13.

Peterson, C. G. \& N. B. Grimm, 1992. Temporal variation in enrichment effects during periphyton succession in a nitrogen-limited desert stream ecosystem. Journal of the North American Benthological Society 11: 20-36.

Pohlon, E., A. O. Fandino, \& J. Marxsen, 2013. Bacterial community composition and extracellular enzyme activity in temperate streambed sediment during drying and rewetting. PLoS ONE 8.

Porter, S. D., D. K. Mueller, N. E. Spahr, M. D. Munn \& N. M. Dubrovsky, 2008. Efficacy of algal metrics for assessing nutrient and organic enrichment in flowing waters. Freshwater Biology 53: 1036-1054.

Potapova, M. \& D. F. Charles, 2005. Choice of substrate in algae-based water-quality assessment. Journal of the North American Benthological Society 24: 415-427.

Pound, K. L., G. B. Lawrence \& S. I. Passy, 2019. Beta diversity response to stress severity and heterogeneity in sensitive versus tolerant stream diatoms. Diversity and Distributions 25: 374-384.

R Core Team, 2017. R: A language and environment for statistical computing. R Found. Stat. Comput. Vienna, Austria. http://www.R-project.org/, page R Foundation for Statistical Computing.

Rimet, F. \& A. Bouchez, 2012. Life-forms, cell-sizes and ecological guilds of diatoms in European rivers. Knowledge and Management of Aquatic Ecosystems 1: 406.

Romani, A. M., A. Butturini, F. Sabater, \& S. Sabater, 1998. Heterotrophic metabolism in a forest stream sediment: surface versus subsurface zones. Aquatic Microbial Ecology 16: 143-151.

Romani, A. M. \& S. Sabater, 1997. Metabolism recovery of a stromatolitic biofilm after drought in a Mediterranean stream fig: 3. Archiv für Hydrobiologie 140: 261-271.

Romani, A. M. \& S. Sabater, 2000. Influence of algal biomass on extracellular enzyme activity in river biofilms. Microbial Ecology 40: 16-24.

Romaní, A. M., S. Amalfitano, J. Artigas, S. Fazi, S. Sabater, X. Timoner, I. Ylla \& A. Zoppini, 2013. Microbial biofilm structure and organic matter use in mediterranean streams. Hydrobiologia 719: 43-58.

Rothrock, M. J., \& F. Garcia-Pichel, 2005. Microbial diversity of benthic mats along a tidal desiccation gradient. Environmental Microbiology 7: 593-601.

Sabater, S., 2000. Structure and architecture of a stromatolite from a Mediterranean stream. Aquatic Microbial Ecology 21: 161-168.

Sabater, S. \& K. Tockner, 2009. Effects of hydrologic alterations on the ecological quality of river ecosystems. In Sabater, S. \& D. Barceló (eds.), Water scarcity in the Mediterranean. Springer, New York: 15-39.
Sabater, S., H. Guasch, I. Muñoz \& A. Romani, 2006. Hydrology, light and the use of organic and inorganic materials as structuring factors of biological communities in Mediterranean streams. Limnetica 25: 335-348.

Sabater, S., J. Artigas, C. Durán, M. Pardos, A. M. Romaní, E. Tornés \& I. Ylla, 2008. Longitudinal development of chlorophyll and phytoplankton assemblages in a regulated large river (the Ebro River). Science of the Total Environment 404: 196-206.

Sánchez, E., C. Gallardo, M. A. Gaertner, A. Arribas \& M. Castro, 2004. Future climate extreme events in the Mediterranean simulated by a regional climate model: a first approach. Global and Planetary Change 44: 163-180.

Schwaderer, A. S., K. Yoshiyama, P. De Tezanos Pinto, N. G. Swenson, C. A. Klausmeier \& E. Litchman, 2011. Ecoevolutionary differences in light utilization traits and distributions of freshwater phytoplankton. Limnology and Oceanography 56: 589-598.

Socolar, J. B., J. J. Gilroy, W. E. Kunin \& D. P. Edwards, 2016. How should beta-diversity inform biodiversity conservation? Trends in Ecology \& Evolution 31: 67-80.

Stancheva, R., A. E. Fetscher \& R. G. Sheath, 2012. A novel quantification method for stream-inhabiting, non-diatom benthic algae, and its application in bioassessment. Hydrobiologia 684: 225-239.

Stanley, E. H., S. G. Fisher \& J. B. Jones, 2004. Effects of water loss on primary production: a landscape-scale model. Aquatic Sciences 66: 130-138.

Stevenson, R. J., 1996. An introduction to algal ecology in freshwater benthic habitats. In Stevenson, R. J., M. L. Bothwell \& R. L. Lowe (eds.), Algal ecology. Freshwater benthic ecosystems. Academic Press, New York: 3-30.

Tapolczai, K., A. Bouchez, C. Stenger-Kovács, J. Padisák \& F. Rimet, 2016. Trait-based ecological classifications for benthic algae: review and perspectives. Hydrobiologia 776: 1-17.

Team, R. C., \& Worldwide, C. (2002). The R stats package. R Foundation for Statistical Computing, Vienna, Austria. http://www.R-project.org.

Timoner, X., T. Buchaca, V. Acuña \& S. Sabater, 2014. Photosynthetic pigment changes and adaptations in biofilms in response to flow intermittency. Aquatic Sciences 76: $565-578$.

Tornés, E. \& A. Ruhí, 2013. Flow intermittency decreases nestedness and specialisation of diatom communities in Mediterranean rivers. Freshwater Biology 58: 2555-2566.

Tornés, E. \& S. Sabater, 2010. Variable discharge alters habitat suitability for benthic algae and cyanobacteria in a forested mediterranean stream. Marine and Freshwater Research 61: 441-450.

Vis, M. L. \& R. G. Sheath, 1996. Distribution and systematics of Batrachospermum (Batrachospermales, Rhodophyta) in North America. 9. Section Batrachospermum: description of five new species. Phycologia 35: 124-134.

Von Schiller, D., E. Martí, J. L. Riera \& F. Sabater, 2007. Effects of nutrients and light on periphyton biomass and nitrogen 
uptake in Mediterranean streams with contrasting land uses. Freshwater Biology 52: 891-906.

Whitton, B. A., 1970. Biology of Cladophora in freshwaters. Water research 4: 457-476.

Wu, N., X. Dong, Y. Liu, C. Wang, A. Baattrup-Pedersen \& T. Riis, 2017. Using river microalgae as indicators for freshwater biomonitoring: review of published research and future directions. Ecological Indicators 81: 124-131.

Publisher's Note Springer Nature remains neutral with regard to jurisdictional claims in published maps and institutional affiliations. 